\title{
Pseudotumor de Masson lingual: un posible falso positivo
}

\author{
Masson's pseudotumor of the tongue: a possible false positive
}

\section{Sr. Director:}

De todos es conocida la complejidad que determinadas lesiones orales presentan a la hora de ser evaluadas por el clínico en un intento de clasificarlas como benignas o malignas con el fin de adoptar la actitud terapéutica más adecuada en cada caso. Sin duda la experiencia es un grado en este cometido pero todo aquel que se haya enfrentado a lesiones en esta localización será consciente de la importancia que la confirmación histológica adquiere, máxime en aquellas lesiones sospechosas de malignidad, si bien existe un amplio grupo de tumores y pseudotumores cuya localización oral es infrecuente representando un reto diagnóstico no sólo al clínico o al cirujano sino al mismo patólogo, pues existe tendencia a sobredimensionar lesiones que son remitidas con un diagnóstico de sospecha de malignidad, siempre que el contexto sea el adecuado para el desarrollo de las mismas. Resulta interesante consultar la literatura para entender que la cavidad oral no sólo es una de las puertas de entrada al organismo sino que forma parte importante del sistema digestivo y del organismo en general $y$, por tanto, pueden en ella localizarse lesiones que estamos acostumbrados a asociar con otras ubicaciones. Ese es el caso de nuestra paciente de 45 años a la que se le extirpó una lesión del borde de lengua, ligeramente ulcerada y hemorrágica, nodular y de consistencia blanda de $2 \mathrm{~cm}$. de dimensión máxima. Sin existir antecedentes personales de interés la paciente refería la aparición rápida de la lesión con un crecimiento lento de un par de semanas. La lesión fue remitida al Servicio de Anatomía Patológica con cierta urgencia pues existían indicios más que suficientes para sospechar malignidad. El estudio histológico de la lesión permitió observar una lesión vascular

Figura 1.

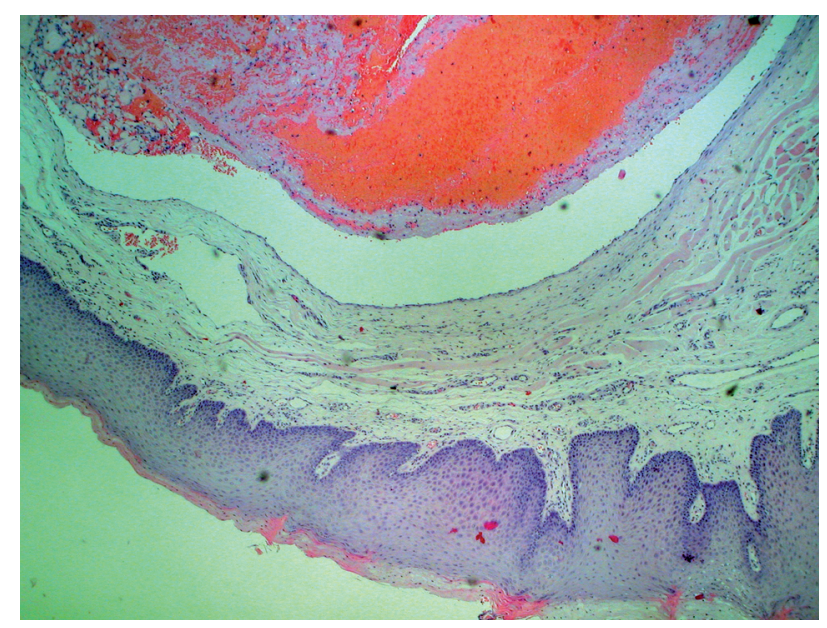

Figure 1.

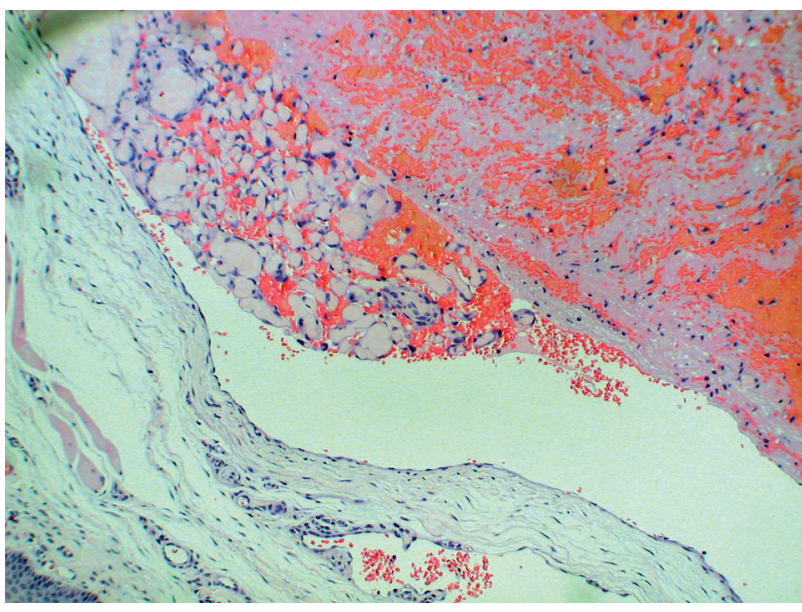

Figura 2.

Figure 2.
Dear Sir,

It is well known that certain oral lesions are very complex for clinicians to evaluate and classify as benign or malignant so that the most appropriate therapeutic attitude can be adopted in each case. Without doubt, experience is a plus in this task, but anyone who has been confronted by these lesions in this location will be conscious of the importance of histological confirmation, and more so when malignancy is suspected. There is, nevertheless, a very large group of tumors and pseudotumors with uncommon oral locations that represent a diagnostic challenge not only for the clinician or surgeon but also for the pathologist, as there is a tendency to over estimate lesions that are sent with a suspected malignancy diagnosis, providing the context is adequate for these to develop.

A review of the literature is interesting in order to understand that the oral cavity in not only one of the doors into the organism, but that it forms an important part of the digestive system and of the organism in general. For this reason lesions may be found in this area that we are accustomed to find elsewhere. This is the case of our patient, aged 45, who underwent excision of a lesion on the edge of her tongue, which was slightly ulcerated and hemorrhaging, nodular and with a soft consistency. Its maximum dimension was $2 \mathrm{~cm}$. There was no personal history of interest and the patient reported the rapid 
relativamente bien delimitada constituida por un lago vascular rico en fibrina adherida a las paredes, recubiertas de endotelio sin alteraciones, si bien un tercio de la circunferencia de la lesión mostraba una hiperplasia papilar fibrosa de la pared igualmente recubierta por endotelio si anomalías. La epidermis suprayacente mostraba acantosis generalizada existiendo una franja dérmica respetada separándola de la lesión vascular (Figs. 1-3). Con tales hallazgos se emitió el diagnóstico de hiperplasia endotelial vascular, más conocida como pseudotumor vascular de Masson. Queremos con la presentación de este caso no sólo aumentar la casuística de lesio-

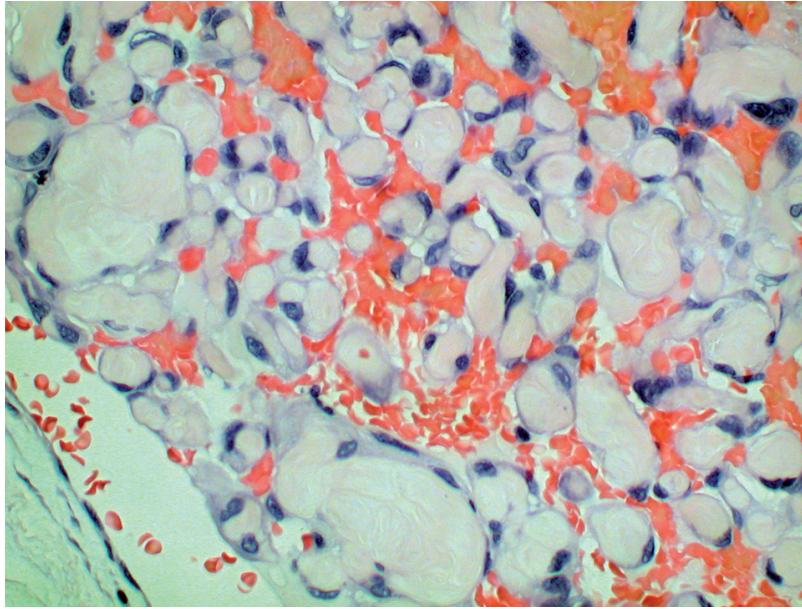

Figura 2. Figure 2. nes infrecuentes de localización oral sino advertir que el continuo traumatismo al que se ve sometida la mucosa oral (incluyendo los comunes bocados) es un estímulo más que suficiente para que un vaso (lingual en nuestro caso) se trombose originando una lesión que tras organizarse puede simular una neoplasia siendo siempre necesario realizar el estudio histológico pertinente para poder garantizar al paciente el tratamiento más adecuado en cada caso.

F.J. Torres Gómez
M. Díaz Delgado

Servicio de Anatomía Patológica Hospital Universitario Virgen Macarena. Sevilla, España

Silvia Gallana Álvarez

Servicio de Cirugía Oral y Maxilofacial Hospital Universitario Virgen Macarena. Sevilla, España appearance of the lesion, which had grown slowly over a few weeks. The lesion was sent to the Department of Pathological Anatomy with certain urgency, as there were more than enough signs to suspect malignancy. The histological study of the lesion showed a relatively well-circumscribed vascular lesion that was made up of a fibrin-rich vascular lake that was adhered to the walls. These were covered by endothelium showing no disturbance, although a third of the circumference of the lesion displayed fibrous papall, which was also covered with endothelium with no abnormality. The overlying epidermis showed general acanthosis and there was a strip of untouched dermis separating it from the vascular lesion. Given these findings, a diagnosis of vascular endothelial hyperplasia, more commonly known as Masson's vascular pseudotumor was given.

With the presentation of this case we would like, not only to increase the casuistry of uncommon oral lesions, but to warn that, given the continuous trauma to which the oral mucosa is subjected (including frequent bites), there is a more than sufficient stimulus for a vessel (lingual in our case) to clot, giving rise to a lesion which can rearrange itself and simulate a neoplasm. Appropriate histological examination is necessary in order to guarantee that, in each case, patients have the most appropriate treatment. 